\title{
Development of prebiotic food products and health benefits
}

\author{
Priscilla Moura ROLIM ${ }^{1 *}$
}

\begin{abstract}
In the current context from the nutritional and epidemiological point of view, it can be seen an occurrence increase of Chronic Non-Communicable Diseases, as well as the inflammatory ones, ordinarily associated to a wrong feed, poor in fibers and rich in fats and simple and refined carbohydrates. This view has evidenced a progressive increase of diseases, highlighting the importance of colonic microbiota as an active mechanism of infectious processes control and modulation of immunologic answer. Therefore, constant the worries related to recovering and maintenance of healthy intestines, stocked with prebiotic nutrients that support the survival of beneficial health agents. This way, researchers and the segment of food industry has encouraged the development of products with prebiotic properties, looking for the health promotion, treatment and diseases prevention, besides the strengthening on the competitive market. This article will embrace the contents about physiologic effects of the main known prebiotic, their potential in relation to fermentatives bacterias, new developed products and used methodologies to the recognition of pre and probiotic functions.
\end{abstract}

Keywords: prebiotics; physiologic effect; functional foods market.

Practical Application: Innovative applicability to the prebiotics is a consumer attitude for maximum efficacy of their functionality.

\section{Introduction}

Production of functional foods containing prebiotic ingredients, is an area that has dominant featuring in the food industry in recent years, and a very promising market, not only for economic reasons but by scientific evidence of its benefits. Consumers are more aware the relationship between good nutrition and increasingly seek for food that in addition to nurture, provide health benefits (Burgain et al., 2011). Aiming to satisfy this new market, some prebiotics, especially inulin and fructooligosaccharide, have been incorporated into a wide variety of foods and beverages that are part of a natural diet as dairy products, breads, cereals, dietary supplements, and others. Through this growth consumers can appreciate tasty meals while promoting beneficial effects to their own health (Coman et al., 2012).

Prebiotics exert a myriad of effects of health promotion, a fact that has attracted an ever growing number of food processing and pharmaceutical industries. Prebiotics are involved in formulating starter culture, maintaining intestinal health, inhibiting cancer, prevention of obesity and constipation. They also seem to promote a positive modulation of the immune system (Delgado et al., 2011). Recent trends about innovative sources of food waste, supplementation of prebiotics in the diet, evaluation to biotechnological synthesis of prebiotics. Researchers around the world are looking for alternatives to improve access to these ingredients, so they start to be known and consumed by the population in general.

This article reviews some of the physiological effects of prebiotic ingredients and developing products, highlighting its potential health and positive perspective for consolidation in the functional foods market.

\section{Methodology}

This article consists of a literature review, in which matters are related to the physiological effects and beneficial to health, characteristics and food applications of prebiotic ingredients. Was used as a source of research, scientific databases, if opting for articles published in the last 15 years, in Portuguese, English and Spanish.

\section{Prebiotic physiologic effects}

Knowledge of prebiotic as dietetics modular to the intestinal microbiota was sourced by the authors Gibson \& Roberfroid (1995) when defined prebiotic as a feeding ingredient resistant to digestion, that has beneficial effects because it is able to selectively stimulate the growth and/or activity of a limited number of bacteria in the colon, when suffering fermentation, getting this way a primary role in the intestinal physiology.

Besides guaranteeing healthy intestines, prebiotics are admittedly important thanks to many facts, as: due to the bioprocess, they produce microbian biomass, increasing the number of defecations, having, this way similar function to the feeding fibers (Mann et al., 2007); They serve as an alternative food to the probiotics, because they inhibit the pathogens multiplication; They prevent diarrhea situations and other diseases like colon cancer; They establish favorable mechanisms 
to imunomodulation; They act in the absorption of calcium and also in lipid metabolism; They act as functional ingredients as sugar and fat substitutes, besides promoting the best sensorial characteristics in food.

Main prebiotic actors are fructan inulin and fructooligossacharides (FOS), no structural polysaccharides in major occurrence among plants, after starch and saccharose. They are considered carbohydrates of reservation, of linear or branched chain, existent in various vegetables species, like onion, celery, asparagus, Jerusalem artichokes, chicory roots, yacon potato, among many others (Quinteros, 2000).

Inulin has linear chain united by links $\beta(2-1)$, important by being resistant to enzymatic hydrolysis of human gastrointestinal, and degree of polymerization from 11 to 65 units of fructose with a terminal glucose. Since inulin hydrolysis FOS chains are formed, containing from 2 to 10 units of fructose (Roberfroid, 2005). Fructan are bifidogenic and not dependent of the size of the chain and the presence or absence of glucose in their composition. It is necessary to highlight inulin because of its major polymerization degree ferments FOS, getting maximum fermentation in the peripheral colon (Lajolo \& Menezes, 2006).

When fructan get to the large intestines they are totally fermented by bacteria that live in the intestines. Colon contain a complex and dynamic microbial ecosystem, with big concentration of bacteria coming up to more than $10^{11}$ to $10^{12}$ units that form colonies for milliliters (UFCmL ${ }^{-1}$ ) (Berg, 1996). A major part of intestinals bacteria is beneficial; however, some species are pathogenic and may be enrolled in the acute or chronic disease development. Considered no pathogenic or beneficial bacteria, bifidobacterium and lactobacilli has positive biologic activities in human health and are common aims of dietetics interventions (Cummings \& Macfarlane, 2002).

Lactobacilli species are widely studied due to their properties that stimulate health. They have an important commercial value to food industry, due to its appliance in milk derivate production and as beginning cultures of fermentation, commonly associated to bread fermentation (Buriti \& Saad, 2007).

Bifidobacteria makes the biggest group on the colon, the one that constitutes more than $25 \%$ of the total of adult intestinal population and $95 \%$ in newborn, promote diverse beneficial effects to the hostess, so as the substratum fermentation having as a final result the production of short-chain fatty acids (SCFA), they are acetate, propionate and butyrate. Beside this SCFA also formed lactate, bacterial biomass and other gases $\left(\mathrm{CO}_{2} \mathrm{H}_{2}\right.$, and methane) (Cherbut, 2002). Butyrate is considered the main resource of energy to colonocytes, acetate and propionate walk around the portal veins and can influence in the metabolism of carbohydrate and lipids (Silveira Rodríguez et al., 2003).

Production of SCFA promotes reduction of $\mathrm{pH}$ that makes a bactericidal action, reduction of serum levels of ammonia by the fermentation of proteins; production of complex B vitamins, increase of mineral absorption, as calcium and magnesium and the improvement of immune answer. Propionate participates of lipid metabolism regulation, because it decreases the liver cholesterol synthesis by the inhibition of hydroxymetylglutaryl coenzyme activity and participation on the regulation of glucose metabolism, promoting the decrease of prandial and insulin answer (Perrin et al., 2002).

Among the most important functions of intestinal microbiotic is its capacity of inhibit the implementation of pathogenic or no pathogenic invaders microorganism, in the mucosa surface acts as a barrier against infections. It also helps in the selective transportation of nutrients, in the stimulus of the immunological system and in the toxins neutralization. Besides that, it participates in the medicine mechanism, cholesterol, in degradation of biliary salt and in the regulation of the urea cycle (Priebe et al., 2002).

Countless factors can influence the type and extension of fermentation of determined substrates. It includes the competition for nutrients, characteristics of microbiotica colonic, the hostess conditions, interaction among bacteria and the individual feeding habits. Biomass and production of lactate and acetate are higher when the substrate contain more fructooligossacharides from a short chain (Perrin et al., 2002).

Bifidogenic effect in inulin has been evidenced in many scientific researches. Menne et al. (2000) also studied the prebiotic effect of inulin in humans, and verified positive modifications in the fecal microbiota composition, especially by the effect of bifidobacteria increase. Rafter et al. (2007) studying patients with colon cancer verified that a symbiotic diet, using inulin, bifidobacteria and lactobacilli, resulted in meaningful increase of fecal microbiota with bifid and lactobacilli, and decrease of Clostridium perfringens.

Nowadays one of the ways of increase the number of beneficial intestinal microorganisms is the use of prebiotic ingredients and to be able to generate the bifidogenic effect is necessary that the counting of cultures prebiotics in the colon be higher or equal to $10^{6} \mathrm{UFCg}^{-1}$ of fecal material (Gibson \& Fuller, 2000).

On the other hand, Passariello et al. (2011), evaluated the efficacy of zinc and prebiotics for treatment of diarrhea in children. Result of the randomized controlled trial showed that the zinc and the prebiotics limit diarrhea duration in patients by stimulating water and electrolyte absorption across gut mucosa and inhibiting the pathogens, respectively. Therapeutic efficacy was attributed to the synergistic relation between the additives.

\section{Immunomodulatory effect}

Although the genetic to be the main factor determining the intestinal flora has a important role in the development of the defense system of the intestinal mucosa and it is believed that many intestinal diseases are related to this immune regulation. The oligosaccharides associated with intestinal bacteria guide the T lymphocytes maturation, closely linked to the prevention of gastrointestinal diseases. This fact is highlighted especially in infants, which will contribute to their future health (Thomas et al., 2010).

Some experts have seen a progressive increase on immunemediated and gut physiology health problems, such as allergies and auto-immune and inflammatory diseases. In this context, the increased use of prebiotic fibres has become a major area of interest within the nutrition researchers. Some mechanisms contributing to altered in vivo immune function induced by 
functional foods may include modulation of the microflora itself, improved barrier function and direct effects of bacteria on different epithelial and immune cell types, like a monocytes, macrophages, B cells, T cells and NK cells (Romeo et al., 2010).

Studies reporting effects on immunity with prebiotics, for example in double-blind design, randomised intervention study for 6 weeks with 38 infants, administered doses of galactooligosaccharides (GOS) and fructo-oligosaccharides with 4,5g/day and found the level of bifidobacteria in the intestinal microbiota increased (Scholtens et al., 2006). Study for 12 weeks with 74 elderly subjects found decreased levels of pro-inflammatory gene transcription activation with $1,3 \mathrm{~g}$ /day of oligosaccharides (Vulevic et al., 2008). In a multicenter study with 342 healthy infants using $0,4 \mathrm{~g} / 100 \mathrm{ml} /$ day of GOS/FOS found reduced intestinal and respiratory infections during the first year of life (Bruzzese et al., 2009).

Prebiotics have been extensively studied, hereby, they may become an ideal treatment or co-treatment in inflammatory bowel disease, due their capacity to increase endogenous lactobacilli and bifidobacterium. Advances in pathogenesis of intestinal inflammation, suggesting prebiotics should be useful in this disorders. The use of prebiotics as inulin and FOS, has led to decreased chronic inflammatory enteropathy of the mouse and is associated with downregulation of the production of IL- 6 and IFN-gamma in the colonic samples (Peña, 2007).

\section{Performance of prebiotics on the calcium and iron bioavailability}

Some metabolic factors have been associated with prebiotics in relation to absorption of micronutrients such as calcium and iron, however, it is known that more research is needed to support these findings. There have been few randomized controlled studies with small numbers of subjects who have evaluated the absorption of calcium after the administration of prebiotics (FOS, GOS, inulin or combinations). Study randomized with subjects was shown that inulin administered over a year, not only improved calcium absorption but also the bone mineral density per year (Olveira Fuster \& González-Molero, 2007).

Yacon (Smallanthus sonchifolius) roots have been considered a functional food due to the high levels of fructans they contain. Another study evaluated $\mathrm{Ca}$ and $\mathrm{Mg}$ balance, bone mass and strength, and caecum mucosal morphometry in male wistar rats supplemented with yacon flour (5-7\% fructooligosaccharides) during 27 days. Yacon flour consumption resulted in a positive $\mathrm{Ca}$ and $\mathrm{Mg}$ balance, leading to higher values of bone mineral retention and biomechanical properties (peak load and stiffness) when compared to the control group. The positive effects on mineral intestinal absorption, bone mass and biomechanical properties showed an important role of yacon roots in the maintenance of healthy bones (Lobo et al., 2007).

The prebiotics intake appears to prevent the iron malabsorption and anemia. With the purpose to evaluate the effect of dietary supplementation with a combination of two prebiotics (GOS and polydextrose) in iron absorption in gastrectomized rats, Santos et al. (2011) showed that mice supplemented had serum iron concentrations significantly higher than those fed the control diet. Studies in animals have shown that short chain fatty acids, in particular propionate appears to increase iron absorption in the proximal colon. This could indicate a potential mechanism by which the intake of prebiotics increase the availability of dietary iron.

\section{Prebiotics, intestinal complications and cancer}

The dietary fiber is a wider term that refers to different carbohydrates and lignin that resist hydrolysis by human digestive enzymes, but can be fermented by colonic microflora or partially excreted in the feces. This definition would include within the concept of fiber the no starch polysaccharides (cellulose, hemicellulose, pectins, gums, betaglucans), inulin, FOS, GOS, resistant starch. Some of these fiber components satisfy strictly criteria to be considered as prebiotics (inulin, FOS, GOS, soy oligosaccharides) (World Health Organization, 2004).

In this topic we will highlight some complications and intestinal diseases such as diarrhea, ulcerative colitis and colon cancer. Prebiotics have been studied less extensively, however, they may become an ideal treatment or co-treatment option due to their capacity to increase endogenous lactobacillus and bifidobacteria. Probiotics and prebiotics may offer a new therapeutic option for the treatment of inflammatory bowel disease, however, a greater understanding of the mechanisms behind their action on the gastrointestinal microbiota is required in order to determine which probiotic, prebiotic or combinations there are the most beneficial (Geier et al., 2007).

The use of prebiotics as unique treatment or associated with probiotic (symbiotic) also proposed in inflammatory bowel disease in brackets by its effect on the growth of endogenous lactobacilli and bifidobacteria, favoring: the production of short chain fatty acids (especially butyrate, which is a preferential nutrient to enterocytes), prevention of adhesion of pathogenic bacteria, production of antibiotics and decreased intraluminal pH (Olveira Fuster \& González-Molero, 2007).

Prebiotics improves the function or viability of probiotics via their fermentation, but their effect on the adherence of probiotics is still unclear. Kadlec \& Jakubec (2014), examined the effect of 4 commercially available prebiotics and 3 simple saccharides (glucose, galactose, and lactose) on the adherence of 5 probiotic type strains, 2 lactococci starter cultures, and 5 potential dairy probiotic strains. Adherence was tested in microtiter plates with porcine mucus or cocultures of the human colon cell lines Caco 2 and HT29. Prebiotics decreased adherence of the tested strains observed on all types of substrate.

Orrhage et al. (1994) assumed selected microorganisms would be able to protect the host against carcinogenic activities through three mechanisms: Probiotics were able to inhibit the bacteria responsible for converting pre-carcinogenic substances (example polycyclic aromatic hydrocarbons and nitrosamines) in carcinogenic; Studies on lab animals have shown that some probiotic directly inhibit the formation of tumor cells; Some bacteria of the gut flora has demonstrated ability to link and carcinogenic inactivation. 
Research has been carried out to study the effect of prebiotics in the response of acute phase proteins in patients with hematological cancer submitted to chemotherapy. The supplemented group, corroborating other studies showed significant increase in the amount of bifidobacteria. The study suggests that bifidobacteria might have supported the reduction of inflammatory processes and consequently lower metabolic demand like a protein catabolism (Búrigo et al., 2007).

Although many studies demonstrating the importance of prebiotics and probiotics in health maintenance and prevention of intestinal diseases and cancer, their intake is not common in diets of most of the world population. In this case, health professionals such as health professionals, should be responsible for keeping people informed and encourage the use of functional ingredients containing pro and prebiotics, making it a daily practice in food.

A summary of the main benefits imparted to the consumption of prebiotics is indicated in Figure 1. Many the functions of prebiotics are part of the portfolio of probiotics functions, as the promoter of such benefits relies in the modulated microbiota.

\section{Prebiotics and diabetes mellitus: what is the relationship?}

There is evidence that the soluble fiber contributes to the reduction of serum glucose and insulin postprandial by increasing the viscosity of the content of nutrients in the small intestine, which delays the release of glucose, glucose connection with the fiber, reducing thus its availability for use, and inhibiting the action of amylase on amido. Inulin and FOS are good gelforming agents and as such influence the absorption of nutrients,

\section{Prebiotic functions}

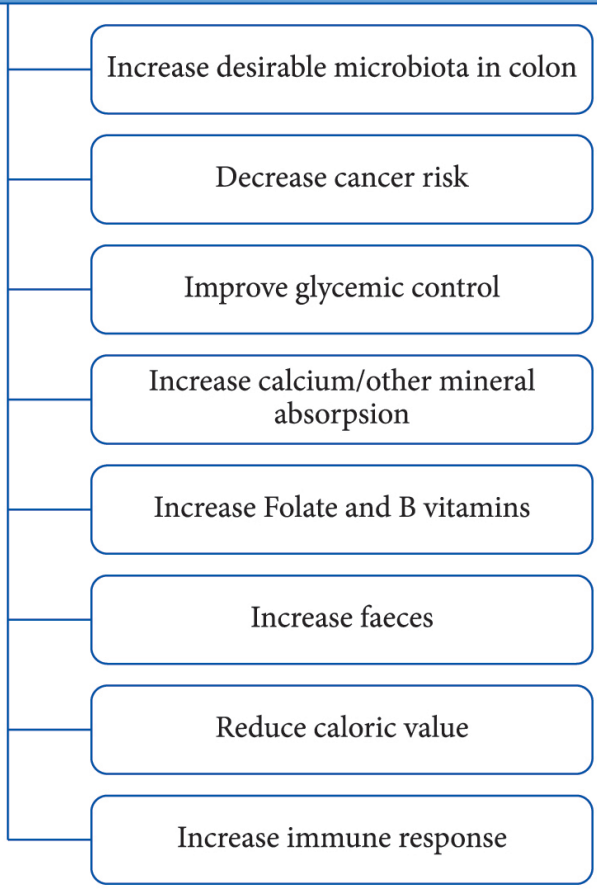

Figure 1. The main prebiotic function. in particular carbohydrate, delaying gastric emptying and/or decreasing the transit time in the intestine delgado (Saad, 2006).

Besides the use of inulin and its derivatives in office technology, it is important to highlight its health benefits, the first of these is its function as dietary fiber, with the physiological effects attributed to this type of compound, such as decreased levels of lipid and glucose blood and its laxative effect. Another effect is the proven ability of inulin modulate the intestinal flora, this is due to its prebiotic effect. The mechanism by which glucose control occurs through the consumption of yacon is still not clearly. One possible explanation is that the components inulin and FOS are very same of soluble fiber, producing slower glucose absorption, characterizing it as a complementary treatment (Albuquerque \& Rolim, 2011).

Research to examine the effects of prebiotic supplementation on satiety and related hormones during a test meal for human volunteers by using a noninvasive micromethod for blood sampling to measure plasma gut peptide concentrations was made by Cani et al. (2009) and they found that prebiotic supplementation was associated with an increase in plasma gut peptide concentrations (glucagon-like peptide 1 and peptide YY), which may contribute in part to changes in appetite sensation and glucose excursion responses after a meal in healthy subjects.

Another research about arabinoxylans showed main nonstarch polysaccharides fraction in many cereal grains. Recent in vitro studies point out that a specific concentrate of long-chain water-extractable arabinoxylans (LC-AX) stimulates specific intestinal microbes like Bifidobacterium longum and launches specific fermentation patterns with potential health benefits for the host (e.g. propionate production). Human trials demonstrate that a long-term administration of LC-AX can restore the glucose and insulin responses in patients suffering from diabetes type II (Van den Abbeele et al., 2011).

Functional foods have become the prized of food innovation in the past few years. All big food companies are investing in functional foods because the mega trends in society seem to require healthy food with added benefits to improve the health, wellness and people life quality.

\section{Development of products with prebiotic allegation}

Nowadays one of the tendencies in food segment is the healthiness and wellness, associated to the growth of food industry in answering the consumer exigencies who is more conscious that an adequate feeding with healthy ingredients are indispensable to a better life wellness to children and adults.

Many researches about of developing food products, involving milk and derivatives, bread, cake, etc., adding value due contain prebiotic ingredients and organisms. It is valid to highlight that these products must positively answer to the nutritional and sensory characteristics, and remain in appropriate conditions during the processing and storage. Studies show that the counting of probiotic bacteria in products already commercialized, especially the milk derivate, are found inside the minimal boundaries recommended, keeping this way a good condition in viability during their shelf lives (Barreto et al., 2003). Food applications are illustrated in Table 1. 
Table 1. Functional properties of prebiotics in foods.

\begin{tabular}{|c|c|}
\hline Applications & Functional properties \\
\hline Yoghurts and desserts & $\begin{array}{l}\text { Sugar replacement, texture and mouthfeel, } \\
\text { fiber, and prebiotics }\end{array}$ \\
\hline Beverages and drinks & $\begin{array}{l}\text { Sugar replacement, mouthfeel, foam } \\
\text { stabilization, and prebiotics }\end{array}$ \\
\hline Breads and fillings & $\begin{array}{l}\text { Fat or sugar replacement, texture, fiber, and } \\
\text { prebiotics }\end{array}$ \\
\hline Meat products & Fat replacement, texture, stability and fiber \\
\hline Dietetic products & Fat or sugar replacement, fiber, and prebiotics \\
\hline Cake and biscuits & $\begin{array}{l}\text { Sugar replacement, moisture retention, fiber, } \\
\text { and prebiotics }\end{array}$ \\
\hline Chocolate & Sugar replacement, heat resistance and fiber \\
\hline Sugar confectionary & Sugar replacement, fiber, and prebiotics \\
\hline Soups and sauces & Sugar replacement, and prebiotics \\
\hline Baby food & $\begin{array}{l}\text { Texture, body and mouthfeel, fiber, stability, } \\
\text { and prebiotics }\end{array}$ \\
\hline
\end{tabular}

Wang (2009).

Prebiotics has also being used in child formulation (Millani et al., 2009) in a way to answer children questions about no have access mother's milk or partially received it. Consumption of these products evidence improvements in allergy cases, crying and colic increase, improvement in the prevention of constipation, among others. However, food industry must be cautious into incorporate prebiotics to child food, considering that studies are still necessary in this area.

A very used ingredient, nowadays, in the development of new products is the yacon potato (Smallanthus sonchifolius), tubercle from the Andes that has been featured because it is rich in FOS and inulin. Yacon can suffer different types of processing to obtain pulps, juices and flours, and these are being added to other food.

As adding yacon potato to breads, Rolim et al. (2011) verified a rich in fiber food, low glycemic index and considerable prebiotic effect, in presenting the bifidobacteria counting and lactobacilli between $10^{7}$ a $10^{10}\left(\mathrm{UFCmL}^{-1}\right)$, possibly being able of colonizing the intestines, once that the minimal recommendation to make the probiotics effects is $10^{6} \mathrm{UFCmL}^{-1}$. Researchers also evaluated the effects of yacon potato flour addition in chocolate cakes, as an alternative in substituting sugar, and had positive results in terms of chemical composition, glycemic index and charge and satisfactory prebiotic capacity (Padilha et al., 2010).

To evaluate the prebiotic effect of a new product, models may be used. Samples can be submitted to the process of fermentation with anaerobic system and addition of an inoculum prepared from the infants faeces. The liquid is used for metabolic bacterial count homo and hetero-fermentative, as well as providing analysis of short-chain fatty acids (SCFA). To count the bacteria can use the differential medium agar also generating system anaerobic. And analysis of SCFA can be performed by gas chromatography (Barry et al.,1995; Vanderzant \& Splittsloesser, 2001).

Rodrigues et al. (2012), investigated the influence of FOS and inulin (50:50) on the free fatty acid profile of cheese, with special emphasis on the conjugated linoleic acid. Linoleic acid content increase during the ripening time suggests the addition of prebiotics in probiotic cheese, to improve quality with lower atherogenicity index.

It is also possible to measure the effect of a prebiotic potential by evaluating the resistance of microorganisms to acid, can be done replied with Man Rogosa Sharp (MRS) broth with accompanying the $\mathrm{pH}$. Other method to evaluate microorganisms it is the resistance to bile using lyophilized bovine bile for monitoring the cell viability at different times (Rönkä et al., 2003; De Man et al., 1960).

Promising research with prebiotics can be produced by sugar solution through transfructosylated reaction (Aachary \& Prapulla, 2009). The solid wastes accumulated in industries when sucrose saturated solutions can synthesize fructooligosaccharides. (Gullón et al., 2011).

Recent technic like a Ultrasound assisted extraction (UAE) also was used to extract oligosaccharides from selected fruits (blueberry, nectarine, raspberry, watermelon) and vegetables (garlic, Jerusalem artichoke, leek, scallion, spring garlic and white onion). UAE increased the concentration of extracted oligosaccharides in all fruits and vegetables from 2 to 4 -fold compared to conventional extraction (Jovanovic-Malinovska et al., 2015).

\section{Effect of prebiotic in sensory acceptance of foods}

Sensory analysis is a decisive phase during the food product development. Morais et al. (2014) developed chocolate dairy dessert with addition of prebiotics and replacement of sucrose with different high-intensity sweeteners. The relative sweetness analysis showed that sweeteners had the highest sweetening power compared with the prebiotic chocolate dairy dessert containing $8 \%$ sucrose. The study of sweetness in this product is important because consumers desire healthier functional products with no added sugar.

Cruz et al. (2013) aimed to evaluate the effect of increasing concentrations of oligofructose addition on physicochemical, rheological and microbiological characteristics of non-flavored yogurt. The addition of oligofructose showed no influence on the $\mathrm{pH}$, proteolysis or the viability of Streptococcus thermophilus or Lactobacillus bulgaricus during 28 days of refrigerated storage $(p>0.05)$.

In another study, inulin was supplemented in bread and results are smaller loaves, harder crumb and darker colour. Sensory studies reflected acceptability decreases with inulin content, yeast invertase and dry heat degrade inulin, and fructo-oligosaccharide/inulin fortification in bread at $5 \%$ seems achievable (Morris \& Morris, 2012).

Study to determine the effect of a prebiotic (fructooligosaccharide) on the sensory properties and consumer acceptability of peach-flavored drinkable yogurts was carry out. The yogurts containing the prebiotic were not significantly different from their comparable controls indicating that a prebiotic can be added without impacting acceptance (Gonzalez et al., 2011). 


\section{Functional food market: a real tendency}

Functional and food ingredients offer benefits to human health: gastrointestinal, cardiovascular, system growth, development, cell differentiation, behavior of functions physiological and as antioxidants. Foods which naturally contains bioactive compounds. Euromonitor International data about food and drink markets associated with health and wellbeing, achieved US $\$ 750$ billion in 2013. In this context, US $\$ 264$ billion represents only the functional or fortified products, foods and drinks have special ingredients to bring in formulas to health benefits for consumers. Currently, Latin America, has US\$ 45 billion or 17\% of the functional food and drinks market.

Aligned with the trends of this market, many industries have invested in scientific research and technological innovation in the development of products referenced by their functional properties. This segment includes different types of functional ingredients for the industry food, being used in bakery foods, cereals, drinks and dairy products, and the segment of food supplements. Taking advantage moment, brazilian producers are increasingly investing in these foods that have become trend. In contrast, some challenges are detected, such as the limitations imposed by regulator organ in relation to claims of product benefits, the delay in the registration period, the lack of clinical trials to advance the applicability of the products and the difficulty of researching new substances originated mainly from native flora. Even so, the category of functional foods featured 91 new records in 2013, against 178 recorded between 2011 and 2012. Currently, the total number of approved products reaches 734 , mainly in the segments allegations functional health and bioactive substances and probiotics with claims of health or functional properties.

\section{Conclusions}

During this chapter it was tried to prove the relevance of prebiotics in the benefits of probiotics and its appliances in food products. However, new analytics analyses are necessary with instrumental methods to determine the fructan fractions in raw material and products, as well as characterize in a selective way the probiotic bacteria using specific collective ways to these genres. Introduction of functional compounds like prebiotics in the diet seems to be an attractive alternative. Owing to its wide range of preventive and therapeutic possibilities prebiotics research certainly catching momentum.

\section{References}

Aachary, A. A., \& Prapulla, S. G. (2009). Value addition to spent osmotic sugar solution (SOS) by enzymatic conversion to fructooligosaccharides (FOS), a low calorie prebiotic. Innovative Food Science \& Emerging Technologies, 10(2), 284-288. http://dx.doi. org/10.1016/j.ifset.2008.11.013.

Albuquerque, E. N., \& Rolim, P. M. (2011). Potencialidades do yacon (Smallanthus sonchifolius) no diabetes Mellitus. Revista de Ciências Médicas, 20(3/4), 99-108.

Barreto, G. P. M., Silva, N., Silva, E. N., Botelho, L., Yim, D. K., Almeida, C. G., \& Saba, G. L. (2003). Quantificação de Lactobacillus acidophilus, bifidobactérias e bactérias totais em produtos probióticos comercializados no Brasil. Brazilian Journal of Food Technology, 6(1), 119-126.

Barry, J. L., Hoebler, C., Macfarlane, G. T., Macfarlane, S., Mathers, J. C., Reed, K. A., Mortensen, P. B., Nordgaard, I., Rowland, I. R., \& Rumney, C. J. (1995). Estimation of the fermentability of dietary fibre in vitro: a European interlaboratory study. The British Journal of Nutrition, 74(3), 303-322. http://dx.doi.org/10.1079/BJN19950137. PMid:7547846

Berg, R. D. (1996). The indigenous gastrointestinal microflora. Trends in Microbiology, 4(11), 430-435. http://dx.doi.org/10.1016/0966842X(96)10057-3. PMid:8950812

Bruzzese, E., Volpicelli, M., Squeglia, V., Bruzzese, D., Salvini, F., Bisceglia, M., Lionetti, P., Cinquetti, M., Iacono, G., Amarri, S., \& Guarino, A. (2009). A formula containing galacto- and fructo-oligosaccharides prevents intestinal and extra-intestinal infections: an observational study. Clinical Nutrition (Edinburgh, Scotland), 28(2), 156-161. http:// dx.doi.org/10.1016/j.clnu.2009.01.008. PMid:19231042

Burgain, J., Gaiani, C., Linder, M., \& Scher, J. (2011). Encapsulation of probiotic living cells: From laboratory scale to industrial applications. Journal of Food Engineering, 104(4), 467-483. http:// dx.doi.org/10.1016/j.jfoodeng.2010.12.031.

Búrigo, T., Fagundes, R. L. M., Trindade, E. B. S. M., Vasconcelos, H. C. F. F., Massaut, I. H. B., \& Rotolo, M. A. S. (2007). Ação do prebiótico sobre as proteínas de fase aguda de pacientes com neoplasia hematológica. Rev Bras Hematol Hemoter, 29(2), 130-135. http:// dx.doi.org/10.1590/S1516-84842007000200010.

Buriti, F. C. A., \& Saad, S. M. I. (2007). Bactérias do grupo Lactobacillus casei: caracterização, viabilidade como probióticos em alimentos e sua importância para a saúde humana. Archivos Latinoamericanos de Nutrición, 57(4), 373-380. PMid:18524322.

Cani, P. D., Lecourt, E., Dewulf, E. M., Sohet, F. M., Pachikian, B. D., Naslain, D., De Backer, F., Neyrinck, A. M., \& Delzenne, N. M. (2009). Gut microbiota fermentation of prebiotics increases satietogenic and incretin gut peptide production with consequences for appetite sensation and glucose response after a meal. The American Journal of Clinical Nutrition, 90(5), 1236-1243. http://dx.doi.org/10.3945/ ajcn.2009.28095. PMid:19776140

Cherbut, C. (2002). Inulin and oligofructose in the dietary fibre concept. The British Journal of Nutrition, 87(Suppl. 2), S159-S162. http:// dx.doi.org/10.1079/BJN2002532. PMid:12088513

Coman, M. M., Cecchini, C., Verdenelli, M. C., Silvi, S., Orpianesi, C., \& Cresci, A. (2012). Functional foods as carriers for $\mathrm{SYNBIO}^{\circ}$, a probiotic bacteria combination. International Journal of Food Microbiology, 157(3), 346-352. http://dx.doi.org/10.1016/j.ijfoodmicro.2012.06.003. PMid:22727086

Cruz, A. G., Cavalcanti, R. N., Guerreiro, L. M. R., Sant’Ana, A. S., Nogueira, L. C., Oliveira, C. A. F., Deliza, R., Cunha, R. L., Faria, J. A. F., \& Bolini, H. M. A. (2013). Developing a prebiotic yogurt: rheological, physico-chemical and microbiological aspects and adequacy of survival analyses methodology. Journal of Food Engineering, 114(3), 323-330. http://dx.doi.org/10.1016/j.jfoodeng.2012.08.018.

Cummings, J. H., \& Macfarlane, G. T. (2002). Gastrointestinal effects of prebiotics. The British Journal of Nutrition, 87(Suppl. 2), S145-S151. http://dx.doi.org/10.1079/BJN/2002530. PMid:12088511

De Man, J. C., Rogosa, M., \& Sharpe, M. E. (1960). A medium for the cultivation of Lactobacilli. The Journal of Applied Bacteriology, 23(1), 130-135. http://dx.doi.org/10.1111/j.1365-2672.1960.tb00188.x.

Delgado, G. T. C., Tamashiro, W. M. S. C., Maróstica Junior, M. R., Moreno, Y. M. F., \& Pastore, G. M. (2011). The putative effects of prebiotics as immunomodulatory agents. Food Research International, 44(10), 3167-3173. http://dx.doi.org/10.1016/j.foodres.2011.07.032. 
Geier, M. S., Butler, R. N., \& Howarth, G. S. (2007). Inflammatory bowel disease: current insights into pathogenesis and new therapeutic options; probiotics, prebiotics and synbiotics. International Journal of Food Microbiology, 115(1), 1-11. http://dx.doi.org/10.1016/j. ijfoodmicro.2006.10.006. PMid:17137666

Gibson, G. R., \& Fuller, R. (2000). Aspects of in vitro and in vivo research approaches directed toward identifying probiotics and prebiotics for human use. The Journal of Nutrition, 130(Suppl. 2), 391S-395S. PMid:10721913.

Gibson, G. R., \& Roberfroid, M. B. (1995). Dietary modulation of the human colonic microbiota: introducing the concept of prebiotics. The Journal of Nutrition, 125(6), 1401-1412. PMid:7782892.

Gonzalez, N. J., Adhikari, K., Sancho-Madriz, \& M. F. (2011). Sensory characteristics of peach-flavoured yoghurt drinks containing prebiotics and synbiotics. LWT - Food Science Technology, 44(1), 158-163. http://dx.doi.org/10.1016/j.lwt.2010.06.008.

Gullón, P., González-Muñoz, M. J., \& Parajó, J. C. (2011). Manufacture and prebiotic potential of oligosaccharides derived from industrial solid wastes. Bioresource Technology, 102(10), 6112-6119. http:// dx.doi.org/10.1016/j.biortech.2011.02.059. PMid:21392971

Jovanovic-Malinovska, R., Kuzmanova, S., \& Winkelhausen, E. (2015). Application of ultrasound for enhanced extraction of prebiotic oligosaccharides from selected fruits and vegetables. Ultrasonics Sonochemistry, 22, 446-453. http://dx.doi.org/10.1016/j. ultsonch.2014.07.016. PMid:25116595

Kadlec, R., \& Jakubec, M. (2014). The effect of prebiotics on adherence of probiotics. Journal of Dairy Science, 97(4), 1983-1990. http:// dx.doi.org/10.3168/jds.2013-7448. PMid:24485681

Lajolo, F. M., \& Menezes, E. W. (2006). Carbohidratos en alimentos regionales Iberoamericanos. São Paulo: Universidade de São Paulo.

Lobo, A. R., Colli, C., Alvares, E. P., \& Filisetti, T. M. (2007). Effects of fructans-containing yacon (Smallanthus sonchifolius Poepp and Endl.) flour on caecum mucosal morphometry, calcium and magnesium balance, and bone calcium retention in growing rats. The British Journal of Nutrition, 97(4), 776-785. http://dx.doi. org/10.1017/S0007114507336805. PMid:17349092

Mann, J., Cummings, J. H., Englyst, H. N., Key, T., Liu, S., Riccardi, G., Summerbell, C., Uauy, R., van Dam, R. M., Venn, B., Vorster, H. H., \& Wiseman, M. (2007). FAO/WHO scientific update on carbohydrates in human nutrition: conclusions. European Journal of Clinical Nutrition, 61(Suppl. 1), S132-S137. http://dx.doi.org/10.1038/ sj.ejcn.1602943. PMid:17992184

Menne, E., Guggenbuhl, N., \& Roberfroid, M. (2000). Fn-type chicory inulin hydrolysate has a prebiotic effect in humans. The Journal of Nutrition, 130(5), 1197-1199. PMid:10801918.

Millani, E., Konstantyner, T., \& Taddei, J. A. A. C. (2009). Effects of prebiotics (oligosaccharides) use on child's health. Revista Paulista de Pediatria, 27(4), 436-446. http://dx.doi.org/10.1590/S010305822009000400014.

Morais, E. C., Morais, A. R., Cruz, A. G., \& Bolini, H. M. A. (2014). Development of chocolate dairy dessert with addition of prebiotics and replacement of sucrose with different high-intensity sweeteners. Journal of Dairy Science, 97(5), 2600-2609. http://dx.doi.org/10.3168/ jds.2013-7603. PMid:24612793

Morris, C., \& Morris, G. A. (2012). The effect of inulin and fructooligosaccahride supplementation on the textural, rheological and sensory properties of bread and their role in wheigh management: a review. Food Chemistry, 133(2), 237-248. http://dx.doi.org/10.1016/j. foodchem.2012.01.027.
Olveira Fuster, G., \& González-Molero, I. (2007). Probióticos y prebióticos en la práctica clínica. Nutrición Hospitalaria, 22(Suppl 2), 26-34. PMid:17679291.

Orrhage, K., Sillerström, E., Gustafsson, J. A., Nord, C. E., \& Rafter, J. (1994). Binding of mutagenic heterocyclic amines by intestinal and lactic acid bacteria. Mutation Research, 311(2), 239-248. http:// dx.doi.org/10.1016/0027-5107(94)90182-1. PMid:7526189

Padilha, V. M., Rolim, P. M., Salgado, S. M., Livera, A. S., Andrade, S. A. C., \& Guerra, N. B. (2010). Perfil sensorial de bolos de chocolate formulados com farinha de yacon (Smallanthus sonchifolius). Food Science and Technology (Campinas), 30(3), 735-740. http://dx.doi. org/10.1590/S0101-20612010000300026.

Passariello, A., Terrin, G., De Marco, G., Cecere, G., Ruotolo, S., Marino, A., Cosenza, L., Tardi, M., Nocerino, R., \& Berni Canani, R. (2011). Efficacy of a new hypotonic oral rehydration solution containing zinc and prebiotics in the treatment of childhood acute diarrhea: a randomized controlled trial. The Journal of Pediatrics, 158(2), 288-92. e1. http://dx.doi.org/10.1016/j.jpeds.2010.07.055. PMid:20828714

Peña, A. S. (2007). Flora intestinal, probióticos, prebióticos, simbióticos y alimentos novedosos. Revista Espanola de Enfermedades Digestivas, 99(11), 653-658. http://dx.doi.org/10.4321/S1130-01082007001100006. PMid:18271664

Perrin, S., Fougnies, C., Grill, J. P., Jacobs, H., \& Schneider, F. (2002). Fermentation of chicory fructo-oligosaccharides in mixtures of different degrees of polymerization by three strains of bifidobacteria. Canadian Journal of Microbiology, 48(8), 759-763. http://dx.doi. org/10.1139/w02-065. PMid:12381033

Priebe, M. G., Vonk, R. J., Sun, X., He, T., Harmsen, H. J., \& Welling, G. W. (2002). The physiology of colonic metabolism. Possibilities for interventions with pre- and probiotics. European Journal of Nutrition, 41(Suppl. 1), I2-I10. PMid:12420110.

Quinteros, E. T. T. (2000). Produção com tratamento enzimático e avaliação do suco de yacon (Tese de Doutorado). Faculdade de Engenharia de Alimentos, Universidade Estadual de Campinas, Campinas.

Rafter, J., Bennett, M., Caderni, G., Clune, Y., Hughes, R., Karlsson, P. C., Klinder, A., O’Riordan, M., O'Sullivan, G. C., Pool-Zobel, B., Rechkemmer, G., Roller, M., Rowland, I., Salvadori, M., Thijs, H., Van Loo, J., Watzl, B., \& Collins, J. K. (2007). Dietary synbiotics reduce cancer risk factors in polypectomized and colon cancer patients. The American Journal of Clinical Nutrition, 85(2), 488496. PMid:17284748.

Roberfroid, M. B. (2005). Introducing inulin-type fructans. The British Journal of Nutrition, 93(Suppl. 1), S13-S25. http://dx.doi.org/10.1079/ BJN20041350. PMid:15877886

Rodrigues, D., Rocha-Santos, T. A. P., Gomes, A. M., Goodfellow, B. J., \& Freitas, A. C. (2012). Lipolysis in probiotic and symbiotic cheese: the influence of probiotic bacteria, prebiotic compounds and ripening time on free fatty acid profiles. Food Chemistry, 131(4), 1414-1421. http://dx.doi.org/10.1016/j.foodchem.2011.10.010.

Rolim, P. M., Salgado, S. M., Padilha, V. M., Livera, A. V. S., Andrade, S. A. C., \& Guerra, N. B. (2011). Glycemic profile and prebiotic potential "in vitro" of bread with yacon (Smallanthus sonchifolius) flour. Food Science and Technology (Campinas), 31(2), 467-474. http://dx.doi.org/10.1590/S0101-20612011000200029.

Romeo, J., Nova, E., Wärnberg, J., Gómez-Martínez, S., Díaz Ligia, L. E., \& Marcos, A. (2010). Immunomodulatory effect of fibres, probiotics and synbiotics in different life-stages. Nutrición Hospitalaria, 25(3), 341-349. PMid:20593114.

Rönkä, E., Malinen, E., Saarela, M., Rinta-Koski, M., Aarnikunnas, J., \& Palva, A. (2003). Probiotic and milk technological properties of Lactobacillus brevis. International Journal of Food Microbiology, 
83(1), 63-74. http://dx.doi.org/10.1016/S0168-1605(02)00315-X. PMid:12672593

Saad, S. M. I. (2006). Probióticos e prebióticos: o estado da arte. Revista Brasileira de Ciências Farmacêuticas, 42(1), 1-16. http://dx.doi. org/10.1590/S1516-93322006000100002.

Santos, E. F., Tsuboi, K. H., Araújo, M. R., Falconi, M. A., Ouwehand, A. C., Andreollo, N. A., \& Miyasaka, C. K. (2011). A ingestão de prébioticos previne a malabsorção de ferro e anemia induzidas pela gastrectomia?: Estudo experimental em ratos. ABCD. Arquivos Brasileiros de Cirurgia Digestiva (São Paulo), 24(1), 9-14. http:// dx.doi.org/10.1590/S0102-67202011000100003.

Scholtens, P. A., Alles, M. S., Bindels, J. G., van der Linde, E. G., Tolboom, J. J., \& Knol, J. (2006). Bifidogenic effects of solid weaning foods with added prebiotic oligosaccharides: a randomised controlled clinical trial. Journal of Pediatric Gastroenterology and Nutrition, 42(5), 553-559. http://dx.doi.org/10.1097/01.mpg.0000221887.28877. c7. PMid: 16707980

Silveira Rodríguez, M. B., Monereo Megías, S., \& Molina Baena, B. (2003). Alimentos funcionales y nutrición óptima. Cerca o lejos? Revista Espanola de Salud Publica, 77(3), 317-331. http://dx.doi. org/10.1590/S1135-57272003000300003. PMid:12852326
Thomas, D. W., Greer, F. R., American Academy of Pediatrics Committee on Nutrition, \& American Academy of Pediatrics Section on Gastroenterology, Hepatology, and Nutrition (2010). Probiotics and prebiotics in pediatrics. Pediatrics, 126(6), 1217-1231. http:// dx.doi.org/10.1542/peds.2010-2548. PMid:21115585

Van den Abbeele P., Van den Wiele, T., \& Possemiers, S. (2011). Prebiotic effect and potential health benefit of arabinoxylans. Agro Food Industry Hi-Tech, 22(Suppl. 2), 9-12.

Vanderzant, C., \& Splittsloesser, D. F. (2001). Compendium of methods for the microbiological examination of foods (4th ed.). Washington: American Public Health Association.

Vulevic, J., Drakoularakou, A., Yaqoob, P., Tzortzis, G., \& Gibson, G. R. (2008). Modulation of the fecal microflora profile and immune function by a novel trans-galactooligosaccharide mixture (B-GOS) in healthy elderly volunteers. The American Journal of Clinical Nutrition, 88(5), 1438-1446. PMid:18996881.

Wang, Y. (2009). Prebiotics: Present and future in food science and technology. Food Research International, 42(1), 8-12. http://dx.doi. org/10.1016/j.foodres.2008.09.001.

World Health Organization - WHO. (2004). Diet, nutrition and prevention of chronic diseases: report of a joint WHO/FAO expert consultation (WHO Technical Report Series, 916, pp. 1-149). Geneva: WHO. 